\title{
Characterization of the milk production chain and study of the dairy herd health in the city of Codó, Maranhão
}

\section{Caracterização da cadeia produtiva do leite e estudo da sanidade do rebanho leiteiro no município de Codó, Maranhão}

\author{
Humberto de Campos ${ }^{1}$ (i) (https://orcid.org/0000-0001-6580-6249) \\ Ana Raysa Verde Abas ${ }^{2}$ (1) (https://orcid.org/0000-0001-9799-0378) \\ Aline Barbosa de Oliveira ${ }^{3}$ (1) (https://orcid.org/0000-0002-3407-867X) \\ Rayane Leite Santos ${ }^{3}$ (i) (https://orcid.org/0000-0001-9823-243X) \\ Andressa Emily Frasão Reis ${ }^{4}$ (1) (https://orcid.org/0000-0002-4556-522X) \\ Leticia de Melo da Silva4 (10) (https://orcid.org/0000-0002-8753-7251) \\ Luciana da Silva Bastos 5 (1) (http://orcid.org/0000-0002-7916-9911) \\ Isabel Azevedo Carvalho6 (1) (http://orcid.org/0000-0002-8917-0692) \\ Francisca Neide Costa6* (1) (https://orcid.org/0000-0002-8941-241X)
}

\begin{abstract}
In order to characterize the milk production chain and study the dairy herd health in the city of Codó, state of Maranhão, Brazil, a checklist was applied and tests were carried out to detect clinical and subclinical mastitis using mastitis test strip cup and the California mastitis test (CMT), from June to August 2019, in 295 dairy cows from 20 farms. Water and milk samples were collected for microbiological analysis. It was observed that herdsmen do not have adequate knowledge about good agricultural practices. As for milking, only $60 \%$ are performed in corrals with coverage, and as for the floor, $60 \%$ are made of clay and $40 \%$ are made of concrete. In $35 \%$ of the properties, the water used in milking management comes from wells and the rest from dams. Pre and postdipping practices, CMT, mastitis strip cup test and the adoption of a mastitis control program are not carried out on any of the properties Two cows tested positive for subclinical mastitis and one cow tested positive for tuberculosis. In the microbiological analysis of the milk, a high count of total coliforms and thermotolerants was obtained, with values between 23 to $>1,100 \mathrm{MPN} / \mathrm{mL}$ and $<3.0$ to $>1,100 \mathrm{MPN} / \mathrm{mL}$, respectively. The presence of coagulase positive staphylococci was also observed in $25 \%$ of the samples. The water samples also showed high contamination by total coliforms between 4.1 to $>2.419 .6 \mathrm{MPN} / \mathrm{mL}$ and $40 \%$ showed the presence of Escherichia coli. These results reflect the need for more investments in technical assistance and technical training for these producers.
\end{abstract}

KEYWORDS: good agricultural practices; quality; microbiology; indicators; mastitis.

\begin{abstract}
RESUMO: Este estudo teve como objetivo caracterizar a cadeia produtiva do leite e estudar a sanidade do rebanho leiteiro do município de Codó, estado do Maranhão, Brasil, através da aplicação de um checklist e da realizaçáo de exames para detecção de mastite clínica e subclínica pelos métodos da caneca do fundo escuro e California mastitis test (CMT), no período de junho a agosto de 2019, em 295 vacas leiteiras procedentes de 20 propriedades. Coletaram-se amostras de leite e água da ordenha para análises microbiológicas. Observou-se que os ordenhadores náo possuem conhecimento adequado sobre as boas práticas agropecuárias. Quanto à realização da ordenha, apenas $60 \%$ realizam-na em currais com cobertura; quanto ao piso, $60 \%$ são de terra batida e $40 \%$ de concreto. A água utilizada no manejo da ordenha é proveniente de poços em $35 \%$ das propriedades e as demais de açudes. As práticas de pré e pós-dipping e os testes CMT e caneca de fundo escuro e a adoçáo de programa de controle da mastite não são realizados em nenhuma das propriedades. Diagnosticaram-se duas vacas com mastite subclínica e uma com tuberculose e verificou-se elevada contaminação por coliformes totais e termotolerantes nas análises microbiológicas do leite, variando entre $23 \mathrm{NMP} / \mathrm{mL}$ a $>1.100 \mathrm{NMP} / \mathrm{mL}$ e $<3.0$ a $>1.100 \mathrm{NMP} / \mathrm{mL}$, respectivamente, e presença de estafilococos coagulase positivos em $25 \%$ das amostras. As amostras de água também apresentaram elevada contaminação por coliformes totais entre 4,1 NMP/mL a > 2.419,6 NMP/mL e $40 \%$ apresentaram presença de Escherichia coli. Esses resultados refletem a necessidade de mais investimentos em assistência técnica e treinamento técnico para esses produtores.
\end{abstract}

PALAVRAS-CHAVE: boas práticas agropecuárias; qualidade; microbiologia; indicadores; mastite.

\footnotetext{
'Universidade Estadual do Maranhão - Programa de Pós-graduação Profissional em Defesa Sanitária Animal - São Luís (MA), Brazil.

${ }^{2}$ Agência Estadual de Defesa Agropecuária do Maranhão - São Luís (MA), Brazil.

${ }^{3}$ Universidade Estadual do Maranhão - Programa de Pós-graduação em Ciência Animal - São Luís (MA), Brazil.

${ }^{4}$ Universidade Estadual do Maranhão - Curso de Graduação em Medicina Veterinária - São Luís (MA), Brazil.

${ }^{5}$ Universidade Estadual do Maranhão - Laboratório de Microbiologia de Alimentos e Áqua - São Luís (MA), Brazil.

${ }^{6}$ Universidade Estadual do Maranhão - Centro de Ciências Agrárias - Departamento de Patologia - São Luís (MA), Brazil.

*Corresponding author: francisca.cca.uema@gmail.com

Received on: 2/6/2020. Accepted on: 9/7/2020
} 


\section{INTRODUCTION}

Consumers are increasingly aware that the type of product they eat influences their health, which makes the demands of the consumer market increasingly greater (PAIXÃO et al., 2014). The identity parameters and quality characteristics that milk must have, such as sensory characteristics, physicalchemical parameters and maximum limits for standard plate count and somatic cell count (SCC) must meet the requirements set by the legislation (BRAZIL, 2018) Milk is the product from complete and uninterrupted milking, under hygienic conditions, from healthy, well-fed and rested cows (BRAZIL, 2017). It is a complete food, rich in essential nutrients to life, with the following composition: $87.4 \%$ water, $3.9 \%$ fat, $3.2 \%$ protein, $4.6 \%$ lactose and $0.9 \%$ minerals and vitamins (VILELA, 2001).

Good quality milk has a pleasant taste, high nutritional value, absence of pathogens and contaminants (pesticides, antibiotics etc.), low somatic cell counts and bacterial load, indicative of health and general conditions for handling and hygiene of the herd (PEREIRA et al., 2001).

The Brazilian Ministry of Agriculture, Livestock and Food Supply's Normative Instruction No. 76/2018 (BRAZIL, 2018) determines that establishments must collect monthly milk samples from all tanks, individual and collective, and from cans for microbiological and physical-chemical analysis. Even with the use of technologies, the milk produced in Brazil remains with high bacterial counts, which generates a concern covering all links in the production chain, since better quality generates greater industrial yield (EMBRAPA, 2019). Raw milk with high bacterial counts compromises the quality of pasteurized milk and/or derivatives, making them have a shorter shelf life (ELMOSLEMANY et al., 2009).

Despite accounting for one of the largest dairy herds in the world, with 23 million head, second only to India, milk productivity in Brazil is still considered low, at 1,525 liters/cow/year, one of the lowest rates among the main producing countries, although, in the period from 2000 to 2015 , production increased by $72.3 \%$, the herd increased by $28.7 \%$ and productivity by $33.8 \%$ (IBGE, 2017).

In the city of Codó, state of Maranhão, Brazil, there are 930 properties, 2 of which with buffaloes (22 animals) and 928 with cattle (120,744 animals). Of these 928 properties, only 42 are dairy productors with 1,830 animals (1.515\%), of which 1,098 (60\%) in milking with an average daily production estimated at 6.0 liters/ cow/day (BRAZIL, 2019).

This characteristic has brought investments to the sector and, currently, the city has a milk processing plant with State Inspection Service, which adds value to the product and offers products such as pasteurized milk, yogurt, milk drinks and coalho cheese to the consumer market on a monthly basis.
Considering the importance that the dairy activity represents for the of rural properties and for the development of the Codó region and, consequently, for the state of Maranháo, combined with the poor management practices used to obtain and maintain the quality of chilled raw milk and of the dairy products produced in the city of Codó, in addition to the lack of research work that characterizes the reality of this dairy basin, the present study aimed to characterize the milk production chain and study the health of the dairy herd in the city of Codó, Maranhão.

\section{MATERIAL AND METHODS}

The research was carried out in the city of Codó - MA, from June to August 2019, the dry season in the region, in the milk producing properties that supply the product to the Codó Milk Producers Association. An exploratory research was carried out with qualitative and investigative analysis, through a validated checklist and observations in situ of the routinely hygienic practices used by producers.

A total of 295 dairy cows from 20 farms that supply milk for the dairy of the Codó Milk Producers Association, which make up the dairy basin of the city of Codó, were examined. The sampled herd consisted of primiparous and multiparous cows, in lactation period and in good nutritional status. Milk samples were collected from all lactating cows forming a pool of each property studied, excluding fresh cows (up to the 10th day after calf), cows in the drying phase, and those submitted to antibiotic therapy. In each milked animal, a clinical examination of teats and udder was performed, and then the first three jets of milk were collected in a mastitis test strip cup to detect clinical mastitis. When the result of this test was negative, the California mastitis test (CMT) was performed to detect subclinical mastitis, according to the manufacturer's recommendations.

For microbiological analysis, $900 \mathrm{~mL}$ of milk from the can of each property were aseptically collected, duly identified, packed in isothermal boxes and transported to the Food and Water Microbiology Laboratory of the State University of Maranhão (UEMA), where the microbiological analysis was carried out. The microbiological analysis of the samples was carried out according to the methodology recommended by the Technical Regulation on Microbiological Standards for Food, RDC No. 12 (BRAZIL, 2001).

All data were digitized in spreadsheets of Microsoft Excel version 2010 and subsequently submitted to descriptive statistical analysis and the results. 


\section{RESULTS}

\section{Characterization of herd management on properties}

From the data obtained with check list, it was possible to observe that the handling of milking and the temperature of milk cooling were inadequate, making the process of using and cleaning this equipment deficient. As for milking the animals, $12(60 \%)$ of the milkers perform it in corrals with cover and $8(40 \%)$ without cover, exposing animals to the rain, which may contaminate the milk. As for the type of facilities used, 12 (60\%) producers do premilking, milking and postmilking in corrals containing unpaved floors, and 8 $(40 \%)$ do it in corrals containing concrete floor. Regarding the duration of milking, it is approximately $2 \mathrm{~h}$, with intervals between milkings ranging from 12 to $24 \mathrm{~h}$. The time between the end of milking and the milk delivery at the dairy is approximately 1 to $2 \mathrm{~h}$.

As for the water used in the handling of milking, in $7(35 \%)$ properties it comes from wells and in 13 (65\%) from dams; dam water is stored outdoors without any kind of protection and is more vulnerable to various sources of contamination, for example, contamination by urine and feces from animal, pesticides and other contaminants. Mastitis and diarrhea were the most frequently diseases detected in the studied herds, both with $40 \%$ in all properties under study; $18(90 \%)$ properties do not wash the teats either before or after milking.

Milk from all properties in this study is stored and transported in plastic cans and delivered raw and unrefrigerated to the dairy. Ninety-five percent of the properties deliver to local stores, despite Brazilian legislation prohibiting the sale of raw milk.

Pre- and postdipping practices are not used in any of the properties, and many owners are unaware that these practices are important to reduce the risk of infection, mainly caused by environmental microorganisms.

California mastitis test and mastitis strip cup test are not performed, and the first jets of milk are discarded on the floor or placed directly in the milking container, in all properties under study; none of the properties adopts a mastitis control program or adequate follow-up regarding the use of veterinary drugs. In this study, no case of clinical mastitis was diagnosed, only two cows on two properties were diagnosed with subclinical mastitis.

\section{Raw milk microbiological analysis}

The most probable number (MPN) of total coliforms ranged from 23 to $>1,100 \mathrm{MPN} / \mathrm{mL}$ and for thermotolerant coliforms from $<3.0$ to $>1,100 \mathrm{MPN} / \mathrm{mL}$ (Table 1). Thus, all samples of raw milk are outside the standards established by the Normative Instruction No. 76/2018 for total coliforms, and
Table 1. Most probable number (MPN) of total and thermotolerant coliforms and testing for and coagulase positive staphylococci in raw milk samples - Codó (MA), 2019.

\begin{tabular}{lccc} 
Sample & $\begin{array}{c}\text { Total } \\
\text { coliforms } \\
\text { (MPN/mL) }\end{array}$ & $\begin{array}{c}\text { Thermotolerant } \\
\text { coliforms } \\
\text { (MPN/mL) }\end{array}$ & $\begin{array}{c}\text { Coagulase } \\
\text { positive } \\
\text { staphylococci } \\
\text { (CFU/mL) }\end{array}$ \\
\hline A1 & $>1100$ & 36 & 570 \\
\hline A2 & $>1100$ & 1100 & 620 \\
\hline A3 & 460 & 7.4 & 0 \\
\hline A4 & $>1100$ & $>1100$ & 1100 \\
\hline A5 & $>1100$ & $>1100$ & 0 \\
\hline A6 & $>1100$ & $>1100$ & 450 \\
\hline A7 & $>1100$ & 43 & 0 \\
\hline A8 & 91100 & $>1100$ & 0 \\
\hline A9 & $>1100$ & 210 & 0 \\
\hline A10 & 23 & $>3.0$ & 0 \\
\hline A11 & $>1100$ & $>1100$ & 630 \\
\hline A12 & $>1100$ & $>1100$ & 0 \\
\hline A13 & $>1100$ & $>1100$ & 0 \\
\hline A14 & $>1100$ & $>1100$ & 0 \\
\hline A15 & $>1100$ & $>1100$ & 0 \\
\hline A16 & $>1100$ & $>1100$ & 0 \\
\hline A17 & $>1100$ & 00 & 0 \\
\hline A18 & $>1100$ & $>100$ & 0 \\
\hline A19 & $>1100$ & 0 \\
\hline A20 & $>1100$ & 0 \\
\hline
\end{tabular}

only $2(10 \%)$ samples are within the standards established for thermotolerant coliforms. Salmonella spp. and Escherichia coli were not identified in any of the analyzed samples; coagulase positive staphylococci were detected in $5(25 \%)$ of the analyzed raw milk samples.

\section{Microbiological analysis of water used for milking}

The MPN for total coliforms ranged from 4.1 to 2,419.6 MPN/mL (Table 2), and all samples are not in conformity with the standards established by the Brazilian legislation. Eight (40\%) of the 20 water samples showed contamination by $E$. coli .

\section{Brucellosis analysis}

A total of 102 blood samples from 20 dairy farms that supply milk to the Codó Milk Producers Association were analyzed in order to determine the epidemiological situation of bovine brucellosis in these dairy farms. Only one animal was diagnosed as positive for brucellosis, using the buffered acidified plate antigen test as a screening test. 
Table 2. MPN of total coliforms, $E$. coli and mesophylls in water samples used in the milking of 20 dairy farms in Codó (MA), 2019.

\begin{tabular}{lccc} 
Samples & $\begin{array}{c}\text { Total coliforms } \\
(\text { MPN/100 mL) }\end{array}$ & $\begin{array}{c}\text { E. coli } \\
(\text { MPN/100 } \mathrm{mL})\end{array}$ & $\begin{array}{c}\text { Mesophylls } \\
(\mathrm{MPN} / 100 \mathrm{~mL})\end{array}$ \\
\hline A1 & 344.8 & 0 & $>1146$ \\
\hline A2 & 26.9 & 6.3 & $>1146$ \\
\hline A3 & 82.6 & 60.9 & $>1146$ \\
\hline A4 & 12.1 & 0 & $>1146$ \\
\hline A5 & 344.8 & 0 & $>1146$ \\
\hline A6 & $>2419.6$ & 0 & $>1146$ \\
\hline A7 & 108 & 0 & $>1146$ \\
\hline A8 & 27.5 & 0 & $>1146$ \\
\hline A9 & 2419.6 & 0 & $>1146$ \\
\hline A10 & 29.3 & 0 & $>1146$ \\
\hline A 11 & 0 & 0 & $>1146$ \\
\hline A 12 & 26.9 & 0 & $>1146$ \\
\hline A 13 & 26.9 & 0 & $>1146$ \\
\hline A 14 & 29.3 & 2.0 & $>1146$ \\
\hline A 15 & 0 & 0 & $>1146$ \\
\hline A 16 & 119.1 & 3.1 & $>1146$ \\
\hline A 17 & 12.1 & 6.3 & $>1146$ \\
\hline A 18 & 4.1 & 3.1 & $>1146$ \\
\hline A 19 & 2419.6 & 60.9 & $>1146$ \\
\hline A 20 & 290.5 & 46.7 & $>1146$ \\
\hline & & 0 & \\
\hline
\end{tabular}

All properties carry out vaccination of female calves from 3 to 8 months old and only acquire vaccinated or tested animals with negative results, both for brucellosis and tuberculosis. All owners as well as animal milkers are aware of brucellosis and the risk of transmission of this disease. During the collections, clarifications were provided on the actions and rules of the Brazilian Program for the Control and Eradication of Animal Brucellosis and Tuberculosis.

\section{DISCUSSION}

Disinfection of the teats before (predipping) and after milking (postdipping) are essential measures for mastitis control. The identification of subclinical mastitis in the early stages allows more effective control and reduces the economic impact due to the disposal of contaminated milk or the medications expenses. However, these practices are not carried out on the properties studied, which may have influenced the high microbiological contamination of milk and the presence of mastitis in the herd.

It was observed that good agricultural practices are not adopted in the evaluated properties, thus influencing the quality of the milk obtained. The environment, the milker and the handling adopted during milking are essential factors for good milking practices (ZAFALON et al., 2008).
Indicator microorganisms are used to assess aspects of food and water quality. Despite the legislation establishing limits for coagulase positive staphylococci in raw milk, SILVA et al. (2018) state that only the presence of this pathogen already indicates the possibility of mastitis in the herd. Staphylococci were detected in milk samples from manual milking, suggesting that it is from the hands of milkers.

Salmonella spp. and E. coli were not detected in the raw milk samples. The Brazilian legislation recommends the absence of Salmonella in $25 \mathrm{~g}$ or $25 \mathrm{ml}$ of food. However, there is no specific legislation for these pathogens in raw milk, since it is prohibited to sell raw milk for direct consumption by the population throughout the national territory.

Escherichia coli was detected in $8(40 \%)$ water samples used for milking. The microbiological control of the quality of the water used in dairy farms has great relevance. AMARAL et al. (2004) showed contamination of water samples used in dairy stalls by E. coli, emphasizing the need for this control. JOÁO et al. (2011), in the west of Santa Catarina State also found high counts of heterotrophic bacteria in the water, showing counts of aerobic mesophilic bacteria with an average of $3.2^{10} \mathrm{CFU} / \mathrm{mL}$. The use of drinking water in the cleaning of utensils, equipment, udders of the cows and the hands of milkers during milking is essential for quality milk (BRITO et al., 2003).

According to the Brazilian legislation (BRAZIL, 2017), the water samples in this research are not in accordance with the potability standards. They presented high contamination, which has negative implications on the quality of the milk. The analyzed water samples presented unsatisfactory hygienic-sanitary quality, as the maximum microbiological limit allowed for total coliforms is $<1.0 \mathrm{MPN} / 100 \mathrm{~mL}$ and absence of $E$. coli and, for total mesophilic heterotrophic bacteria count is up to $500 \mathrm{MPN} / 100 \mathrm{~mL}$. In this way, water samples in this study are excessively contaminated, causing risks to the consumers' health and, possibly, being a source of contamination for milk. Probably, the high microbiological contamination of milk in this study was influenced by the poor water quality. According to LAMAS et al. (2015), the water used to clean equipment and other activities can serve as a vehicle for environmental contamination of milk, so it is important that the water used for these purposes is drinkable, presenting low contamination by coliforms and other bacteria.

The water contaminated by $E$. coli in the studied properties implies serious risks of contamination of milk and to the population health. For this reason, milking facilities must have a point of good quality running water, properly chlorinated and with daily control of the chlorine rate.

The animal infected with brucellosis in the herd may be due to management problems, once the type of exploitation, the breeding and sanitary practices may be associated with the risk of infection by the disease, which could affect the dairy herd, resulting in decreased production and risk of infecting other animals in the herd and even the keepers. As was seen in this research, the properties have many deficiencies in the 
management of the herd and the absence of good agricultural practices, resulting in diseases in the herd and low quality of milk.

\section{CONCLUSIONS}

The dairy properties in the city of Codó/MA do not adopt good management practices for the hygienic obtaining of milk, nor measures for the prevention and control of clinical and subclinical mastitis.

The analyzed raw milk had unsatisfactory microbiological quality, evidenced by the detection of mesophilic aerobic indicators and bacteria.

The water used in the dairy properties is not drinkable and may have influenced the quality of the milk.

The milk analyzed presented risks of transmitting pathogens to the consumer, if consumed in natura.

ACKNOWLED GEMENTS: The authors thank to the Universidade Estadual do Maranhão.

FUNDING: This study was financed in part by the Coordenação de Aperfeiçoamento de Pessoal de Nível Superior Brasil (CAPES) Finance Code 001; Fundação de Amparo à Pesquisa e ao Desenvolvimento Científico e Tecnológico do Maranhão.

CONFLICTS OF INTEREST: All authors declare that they have no conflict of interest.

ETHICAL APPROVAL: This study was approved by Comissão de Ética e Experimentação Animal of the Universidade Estadual do Maranhão, under protocol number 47/2018.

AVAILABILITY OF DATA AND MATERIAL: All data generated during this study are included in this published article.

AUTHORS' CONTRIBUTIONS: Conceptualization: Campos, H.; Abas, A.R.V. Data curation: Campos, H.; Abas, A.R.V. Investigation: Campos, H.; Abas, A.R.V.; Oliveira, A.B.; Santos, R.L.: Reis, A.E.; Silva, L.M.; Bastos, L.S.; Carvalho, I.A. Methodology: Costa, F.N. Supervision: Costa, F.N. Writing - original draft: Costa, F.N. Writing - review \& editing: Costa, F.N.

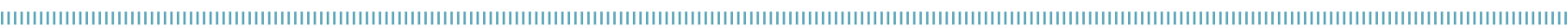

\section{REFERENCES}

\begin{abstract}
AMARAL, L.A.; ROMANO, A.P.M.; NADER FILHO, A.; ROSSI JÚNIOR, O.D. Qualidade da áqua em propriedades leiteiras como fator de risco à qualidade do leite e à saúde da glândula mamária. Arquivos do Instituto Biológico, São Paulo, v.7 1, n.4, p.417-42 1, 2004. Available from: http://www.biologico.agricultura.sp.gov.br/ uploads/docs/arq/V71_4/amaral.PDF. Access on: 17 Oct. 2019.
\end{abstract}

BRAZIL. Agência Estadual de Defesa Agropecuária do Maranhão. Relatório técnico mensal. Resultado oficial da $1^{\text {a }}$ etapa de vacinação contra febre aftosa, Codó - MA. 2019.

BRAZIL. Ministério da Agricultura, Pecuária e Abastecimento . Decreto no. 9.013/2017 de 29 de março de 2017. Regulamento de inspeção industrial e sanitária de produtos de origem animal (RIISPOA). Diário Oficial da União: Brasília, 2017. Available from: http://www.planalto.gov.br/ccivil_03/_Ato2015-2018/2017/ Decreto/D9013.htm. Access on: 17 Oct. 2019.

BRAZIL. Ministério da Agricultura, Pecuária e Abastecimento; Departamento de Inspeção de Produtos de Origem Animal. Instrução Normativa no. 76, de 26 de novembro de 2018. Aprova os Regulamentos Técnicos que fixam a identidade e as características de qualidade que devem apresentar o leite cru refrigerado, o leite pasteurizado e o leite pasteurizado tipo $A$. Diário Oficial da União: Brasília, 2018.
BRAZIL. Ministério da Saúde; Agência Nacional de Vigilância Sanitária. Resolução - RDC n. 12, de 2 de janeiro de 2001. Regulamento técnico sobre os padrões microbiológicos para alimentos. Diário Oficial da União: Brasília, 2001.

BRITO, M.A.V.P.; PORTUGAL, J.A.B.; DINIZ, F.H.; FONSECA, P.C. Qualidade do leite armazenado em tanques de refrigeração comunitários. In: MARTINS, C.E.; FONSECA, P.C.; BERNARDO, W.F.; CÓSER, A.C.; FRANCO, P.R.V.; PORTUGAL, J.A.B.; CARVALHO, F.S. (ed). Alternativas tecnológicas, processuais e de políticas públicas para produção de leite em bases sustentáveis. Juiz de Fora: Embrapa Gado de Leite, 2003. chap.2, p.21-34.

ELMOSLEMANY, A.M.; KEEFE, G.P.; DOHOO, I.R.; JAYARAO, B.M. Risk factors for bacteriological quality of bulk tank milk in Prince Edward Island dairy herds. Part 1: Overall risk factors. Journal of Dairy Science, Champaign, v.92, n.6, p.2634-2643, 2009. https://doi.org/10.3168/jds.2008-1812

EMPRESA BRASILEIRA DEPESQUISA AGROPECUÁRIA (EMBRAPA). Anuário Leite 2019: Novos produtos e novas estratégias da cadeia do leite para ganhar competitividade e conquistar os clientes finais. São Paulo: Texto Comunicação Corporativa, 2019. 104p. (https://ainfo.cnptia.embrapa.br/digital/bitstream/ item/198698/1/Anuario-LEITE-2019.pdf 
INSTITUTO BRASILEIRO DE GEOGRAFIA E ESTATÍSTICA (IBGE). Produção da Pecuária, 2017. Available from: https://cidades. ibge.gov.br/brasil/ma/codo/pesquisa/18/16459?ano=2017. Access on: 30 Jul. 2019.

JOÃO, J.H.; ROSA, C.A.V.L.; THALER NETO, A.; PICININ, L.C.A.; FUCK, J.J.; MARIN, G. Qualidade da água utilizada na ordenha de propriedades leiteiras do Meio Oeste Catarinense, Brasil. Revista de Ciências Agroveterinárias, Lages, v. 10, n.1, p.9-15, 2011 . Available from: https://200.19.105.203/ index.php/agroveterinaria/article/view/5264. Access on: 10 oct. 2019.

LAMAS, J.M.N; MARTINS, M.M; SILVA, F.J.M; MARTINS, E.M.F; BORGES, C.A.V.; OTÊNIO, H.M. Qualidade da água utilizada na limpeza dos tanques de granelização de leite cru: implantação e avaliação da cloração da água para garantia da qualidade do produto. Revista do Instituto de Lacticínios Cândido Tostes, Juiz de Fora, v.70, n.5, p.239-252, 2015 . https://doi. org/10.14295/2238-6416.v70i5.449
PAIXÃO, M.G.; Lopes, M.A.; Pinto, S.M.; Abreu, L.R. Impacto econômico da implantação das boas práticas agropecuárias relacionadas com a qualidade do leite. Revista Ceres, Viçosa, v.61, n.5, p.612-621, 2014.

PEREIRA, D.B.C.; SILVA, P.H.F.; COSTA JÚNIOR, L.C.G.; OLIVEIRA, L.L. Físico-química do leite e derivados: Métodos analíticos. Juiz de Fora: EPAMIG, 2001. 234p.

SILVA, J.G.; ALCÂNTARA, A.M.; MOTA, R.A. Mastite bovina causada por Staphylococcus spp. resistentes à meticilina: revisão de literatura. Pesquisa Veterinária Brasileira, Rio de Janeiro, v.38, n.2, p.223228, 2018. https://doi.org/10.1590/1678-5150-pvb-4996

VILELA, D. A importância econômica, social e nutricional do leite. Revista Batavo, v.3, n. 11 1, p.17-18, 2001. Available from: http:// www.nupel.uem.br/importancia.pdf. Access on: 08 Sep. 2019.

ZAFALON, L.F.; POZZI, C.R.; CAMPOS, F.P.; ARCARO, J.R.P.; SARMENTO, P.; MATARAZZO, S.V. Boas práticas de ordenha (Documentos 78). São Carlos: Embrapa Pecuária Sudeste, 2008. Available from: https:// central3.to.gov.br/arquivo/228631/. Access on: 31 Aug. 2019. 